\title{
Underviserens metodefrihed
}

\section{Bent B. Andresen}

Ph.D., lektor

Arhus Universitet.

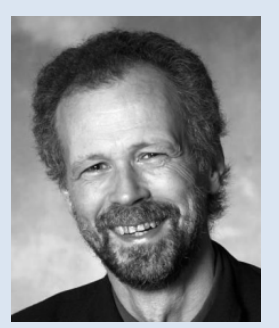

\section{Abstract}

I artiklen behandles omstilling til e-læring og it-støttede undervisningsformer. Set ud fra en fagdidaktisk synsvinkel skaber denne omstilling grobund for øget metodefrihed, hvorved undervisere kan sikre, at mål og indhold præger rammerne for læringen - i stedet for omvendt. Pædagogisk praksis handler blandt andet om at finde en metode $\mathrm{x}$, som sætter de lærende i stand til y. De, der tilrettelægger undervisning, får øget mulighed for at vælge de metoder, som bedst sætter deltagerne i stand til y. Artiklen giver et bud på, hvad de kan gøre i praksis for at skabe øget læringsudbytte.

Som pædagogisk disciplin skaber fagdidaktisk forskning ny og nyttig viden om den ændrede sammenhæng mellem mål, indhold og metode. Inspireret heraf kan underviseren foretage mere kvalificerede metodevalg. Det er hovedtemaet i artiklen. 


\section{Indledning}

E-læring repræsenterer en udvikling i brugen af computere og digitale netværk, men også en fagdidaktisk udvikling. Fagdidaktisk forskning skaber ny og nyttig viden om sammenhængen mellem undervisningens mål (hvorfor), indhold (hvad) og metode (hvordan). Inspireret heraf kan undervisere fokusere på e-læringsmetodik. Herved får de mulighed for at forbedre forholdet mellem fælles undervisning og selvvirksomhed, den faglige dialog samt formidlingen af det faglige indhold.

I artiklen redegøres der for betydningen af at justere blandingsforholdet mellem fælles undervisning og selvvirksomhed med henblik på at styrke deltagernes udbytte af selvstændige læringsaktiviteter. Derpå behandles betydningen af netdialog som et supplement til den dialog, som finder sted, når undervisere og deltagere mødes i et fysisk læringsmiljø. Endvidere redegøres der for betydningen af, at deltagerne făr løbende feedback på deres analyser, produkter og refleksioner via digitale portfolioer.

\section{Undervisningens hvad, hvorfor og hvordan}

Undervisningens hvad og hvorfor omfatter indhold og læringsmål, herunder de faglige arbejdsmetoder, som undervisningen sigter mod, at deltagerne bliver i stand til at mestre. I forbindelse med den igangværende harmonisering på uddannelsesområdet (Bologna-processen) er det hensigten at tydeliggøre, hvad deltagerne bliver i stand til, hvis de gennemfører undervisning i en faglig disciplin. Det er forholdsvist let at fastsætte færdighedsmål. Det er en større udfordring at fastsætte mål for tilegnelse af kompetencer som forståelse, kreativitet og kritisk stillingtagen, men for det meste forudsætter denne kompetenceudvikling, at deltagerne får mulighed for at fremvise deres forståelse (Gardner 2000).

Beherskelse af faglige arbejdsmetoder og udvikling af kompetencer gør det således relevant at fokusere på det, deltagerne foretager sig under et læringsforløb. Da de kun lærer gennem dét, de foretager sig (Larsen 1997), har processen stor betydning for deres læringsudbytte. Gennem forskningsinspireret valg af undervisningens hvordan kan underviserne opnå, at deltagerne både bliver i stand til at mestre relevante, faglige arbejdsmetoder og opfylde kompetencemål med højere kognitive mål. Gennem disse valg kan underviserne også opnå, at deltagerne udvikler væsentlige, overfaglige kompetencer. En afdækning af behovet for denne type kompetencer peger f.eks. på, at deltagerne må være i stand til at handle selvstændigt og refleksivt, at fungere i socialt heterogene grupper og at anvende redskaber interaktivt (OECD 2005).

Ved skemalagt undervisning er der en risiko for, at rammerne påvirker vilkårene for arbejdet med indholdet. Ved tilrettelæggelse af e-læring fastlægges rammerne derimod med udgangspunkt i de faglige arbejds- 
metoder og kompetencemål. Som følge af den øgede metodefrihed kan underviserne tilpasse blandingsforholdet mellem: 1) fælles samlinger, hvor alle deltagere i princippet præsenteres for samme faglige indhold på samme måde, og 2) ligeværdige aktiviteter, hvor de arbejder selvstændigt i læringsfællesskaber og anvender digitale redskaber og medier interaktivt. Denne fagdidaktiske omstillingsproces er ikke lineær, men iterativ. Den kan gennemløbes flere gange med henblik på at øge deltagernes læringsudbytte og mindske frafald.

Til at begynde med kan underviserne skifte fokus fra egen formidling af indhold til dét, deltagerne skal foretage sig under et læringsforløb.

Samtidigt kan underviserne overveje spørgsmål som disse: Er der afsat tilstrækkelig tid til at initiere, gennemføre og evaluere tilrettelagte aktiviteter? Er der behov for at reducere omfanget af fælles sessioner til fordel for perioder, hvor deltagerne foretager sig det, de skal blive i stand til (fig. 1)?

\begin{tabular}{|l|l|l|l|l|l|}
\hline & \multicolumn{4}{|c|}{ Optimering af deltagernes tidsforbrug } \\
\hline $\begin{array}{l}\text { Tidsforbruget til fælles } \\
\text { samlinger inkl. forbere- } \\
\text { delse }\end{array}$ & $90 \%$ & $75 \%$ & $50 \%$ & $25 \%$ & $10 \%$ \\
\hline $\begin{array}{l}\text { Det samlede tidsforbrug } \\
\text { til tilrettelagte, selvstæn- } \\
\text { dige aktiviteter }\end{array}$ & $10 \%$ & $25 \%$ & $50 \%$ & $75 \%$ & $90 \%$ \\
\hline
\end{tabular}

Figur 1.

En undersøgelse på tværs af fag tyder på, at den omtalte form for differentieret e-læring generelt er mere effektiv end traditionel fremmødeundervisning (U.S. Department of Education 2009). Der er således forskningsmæssigt belæg for at indføre e-læringsmetodik. Ved at blande fælles samlinger og tilrettelagte aktiviteter med specifikke læringsmål, samarbejdsformer og deadlines kan underviserne opnå, at deltagerne værdsætter læringsforløbet, frem for at de oplever unødig stress (Andresen 1999). Derudover kan underviserne opnå, at deltagernes læringsudbytte øges, fordi der differentieres i undervisningen.

\section{Differentieret e-læring}

Der kan peges på flere grunde til, at differentieret e-læring giver bedre læringsresultater end traditionel holdundervisning. I det følgende omtales: 1) deltagernes tidsforbrug, 2) forholdet mellem fællessessioner og selvstændige aktiviteter og 3) refleksions- og samarbejdsmuligheder.

Deltagere i e-læringsforløb bruger naturligvis ikke kun tid under fælles samlinger, men også i perioder med selvvirksomhed og ligeværdige aktiviteter. Et forløb kan f.eks. omfatte en samling ved starten, midtvejs og til slut samt to perioder med tilrettelagte, selvstændige læringsaktiviteter. Det er naturligvis muligt at designe mange forskellige forløb med udgangspunkt i denne skabelon og tilrettelægge læringsperiodernes længde og 
antal under hensyntagen til undervisningens hvad og hvorfor. Det er karakteristisk for sådanne forløb, at deltagerne har mere tid til rådighed til sidstnævnte, selvstændige aktiviteter, end de har ved undervisningsformer, som i højere grad er baseret på fremmøde og holdundervisning. Samtidig har underviserne relativt mere tid til vejledning af deltagerne, individuelt og i grupper. Dermed forbedres deltagernes muligheder for at behandle faglige problemstillinger og udfordringer samt gøre erfaringer med arbejdsformer, der styrker deres beherskelse af faglige arbejdsmetoder, og som gør dem i stand til at fremvise forståelse inden for et fagområde.

Desuden kan differentieret e-læring fremme deltagernes refleksioner og øge deres selvkontrol under de selvorganiserede aktivitetsformer. Det forudsætter selvfølgelig, at dét, de foretager sig, har en passende sværhedsgrad. Kravene må hverken være for små eller for store, til at deltagerne kan gennemføre dem med succes, og udfordringerne må falde inde for deres nærmeste udviklingszone.

En yderligere grund til større udbytte af differentieret e-læring er, at denne læringsform kan forbedre deltagernes muligheder for indbyrdes samarbejde. E-læringsforløb omfatter typisk gensidig interaktion mellem deltagerne. Kollaborativ læring er en mere effektiv form for læring end individuel læring, når deltagerne inspirerer og motiverer hinanden samt forpligter hinanden til at overholde deadlines. Denne tilrettelæggelsesform er typisk mere effektiv end individuelt tilrettelagte aktiviteter (Petty 2006). Særligt kan den stimulere deltagerne til at italesætte det, de foretager sig, så faglige begreber bliver en del af deres aktive ordforråd.

En gennemgående problematik på tværs af undervisningsfag vedrører forskellen på deltagernes forhåndsviden og læringspotentialer. I den faglige undervisning er det nødvendigt at gøre forskel på de enkelte deltagere, fordi der $e r$ forskel på disse forudsætninger. Som nævnt er det relevant at differentiere i undervisningen. Begrebet undervisningsdifferentiering betegner et princip for tilrettelæggelse og gennemførelse af undervisning, hvor deltagerne engagerer sig i ligeværdige aktiviteter.

Målene for arbejdet med et fagligt indhold er f.eks. fælles for et hold, mens vejene til at nå disse mål er forskellige. Herved kan deltagerne prioritere at yde en ekstra indsats i arbejdet med opgavebesvarelser, projektfremlæggelser og analyser.

Da der styres på mål frem for på tid, kan de i princippet tage sig den tid, der er nødvendig for at ankomme med succes. Når energien slippes løs, er den enkelte deltager i princippet frit stillet til at bruge ekstra tid. Derved kan deltagere med behov for ekstra tid udvikle faglige færdigheder og faglig forståelse på samme niveau som hurtigt arbejdende deltagere. 
Da underviserne bruger mindre tid til fremmødeundervisning, har de for det meste mere tid til vejledning end ved traditionel holdundervisning, hvilket styrker deres muligheder for at tilpasse omfanget og karakteren af individuel vejledning og feedback til den enkelte deltagers forudsætninger og læringspotentialer. Derudover kan de tage vide hensyn til deltagernes behov i undervisningen. Endvidere kan de tilpasse deres forventninger til bredde og dybde i deltagernes arbejde med faglige materialer.

Individuelt tilpasset materialevalg kan i nogle tilfælde medvirke til at øge læringsudbyttet. Underviserne kan særligt forbedre dette udbytte ved at vælge materialer, som tager vide hensyn til det, deltagerne skal bruge de faglige begreber og arbejdsmetoder til på kortere og længere sigt (Steinmüller 2001).

Hvis deltagerne anvender "tunge tekster", og formålet ikke er at udvikle deres læsefærdigheder, kan de få indholdet læst op på computer. Nogle deltagere har for eksempel gavn af tekst-til-tale, når de skimmer "tunge", faglige tekster, mens andre, mere læseusikre deltagere har gavn af lyttelæsning i de fleste læsesituationer, fordi de derved får adgang til fagligt indhold i tekster, som de ikke er i stand til selv at afkode (Andresen 2007).

Det omfatter informationer om mål og indhold, deadlines, fælles og supplerende materialer, opgavebeskrivelser, øvelsesvejledninger og projektoplæg, som formidles via websteder og digitale læringsplatforme. Underviserne kan for eksempel beskrive arbejdsopgaver, deltagerroller og links til materialer i en WebQuest (Wikipedia 2010), som deltagerne har adgang fra forløbets start. På nogle uddannelsesinstitutioner er underviserne og deltagerne også begyndt at anvende deres mobiltelefoner til dette formål (Bjerre, Christensen og Steinmüller 2009).

\section{Design af e-læringsforløb}

Et e-læringsforløb indledes ofte med, at underviserne initierer det, hvorefter deltagerne reagerer ved enten at spørge, svare eller udføre nogle aktiviteter, som underviserne dernæst reagerer på (Larsen 2006). Deltagerne fordeler derpå den tid, de har til rådighed, mellem dialog med undervisere, dialog andre deltagere, interaktion med det faglige indhold og interaktion med it (fig. 2).

Læringsudbyttet øges, hvis deltagerne kender de regler, der gælder for deres interaktion, fra starten af et forløb (Nordenbo et al. 2008). For at underviserne kan præsentere disse rammer og forventning ved opstarten af et forløb, må de planlægge det i detaljer på forhånd. Det omfatter stillingtagen til, hvad det forventes, at deltagerne fremlægger ved afslutningen af et forløb, og hvordan og i hvilket omfang de kan få vejledning under forløbet. Det omfatter også stillingtagen til, hvordan de kan 
medvirke til at fastsætte læringsmål, vælge indhold, sætte deadlines og lave "netaftaler" i forbindelse med deres indbyrdes interaktion.

Rammerne kan tilrettelægges, så de stimulerer gensidig forpligtende og inspirerende læring. Hensigten er ikke at fremme en underviserstyret tilgang, men at sikre, at deltagerne er klar over, hvad de går ind til, når de går i gang men en ny læringsaktivitet. Hvis designet er utydeligt, kan det være svært for dem at se meningen med og tilrettelægge det, de foretager sig.

Evalueringer peger nærmere bestemt på, at forholdet mellem fremmøde, selvstudier og arbejdet i studiegrupper bliver diffust for deltagerne, hvis de først kan få kendskab til planerne under forløbet (EVA 2003). Derudover kan det nedsætte deres udbytte, hvis de ikke ved, hvilke dele der er baseret på interaktion på hold, og hvilke dele der er baseret på deres selvstændige læringsaktiviteter.

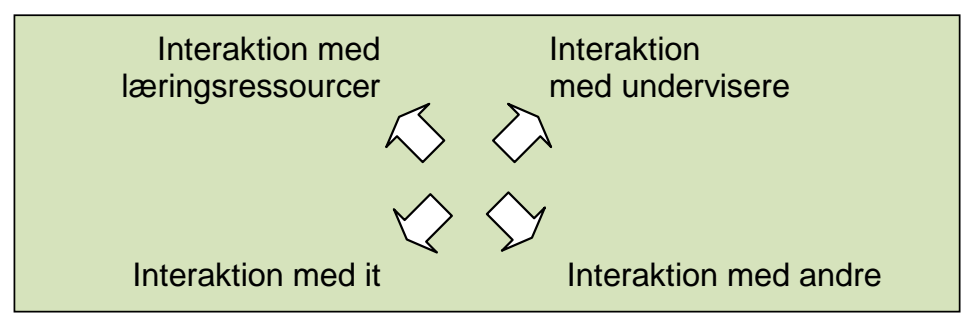

Figur 2.

Forskning om motivation peger på, at to faktorer er afgørende for deltagernes udbytte, dels deres forventninger inden de går i gang med arbejdet, og dels deres værdsættelse heraf (Petty 2006). I den indledende fase af et forløb handler det om at give deltagerne et grundlag for at skabe realistiske og positive forventninger til deres fremtidige læringsaktiviteter. Når det er sket, kan underviseren koncentrere sig om at vejlede og stimulere deltagernes læring. Det er f.eks. ofte en fordel ved projektorganiserede og problemorienterede forløb og aktivitetsformer, hvor deltagerne selv skal søge og bearbejde faglige informationer (for eksempel ved arbejde med WebQuest og isbjergcases).

\section{Netdialog}

Fagdidaktisk forskning på tværs af undervisningsfag har påvist betydningen af, at deltagerne modtager regelmæssig feedback på deres udkast og færdige arbejder. Deres læringsudbytte påvirkes i betydelig grad af en sådan feedback (Black og Wiliam 1998). Ved design af e-læring må under- 
viserne derfor skabe rammer, så de let kan følge fremdriften i deltagernes læring og give handlingsorienteret feedback.

Når underviserne giver feedback, kan de både udtrykke anerkendelse for det, deltagerne præsterer, og undgå at give rituel ros. Desuden kan de henlede deltagernes opmærksomhed på det, de især bør fokusere på i arbejdet fremover med det faglige indhold. Undervisernes relationer til deltagerne har generelt stor betydning for deltagernes læringsudbytte (Nordenbo et al. 2008). Underviserne må derfor skabe rammerne for en tæt, faglig dialog mellem underviserne og deltagerne.

Udover mundtlig interaktion omfatter det som regel skriftlig netdialog. Paradoksalt nok kan mindsket fremmøde styrke interaktionen mellem undervisere og deltagere og befordre et frugtbart samspil mellem parterne omkring deltagernes skriftlige arbejder og undervisernes respons. Som følge heraf kan deltagerne opleve, at de bliver taget mere personligt alvorligt. Muligheden for indlevelse er selvfølgelig størst, hvis underviserne tager vide hensyn til, at den enkelte deltagers læring er lige så individuel som et fingeraftryk.

Den skriftlige dimension vægtes højt i mange faggrupper, idet undervisningen sigter mod, at deltagerne bliver i stand til at formidle faglig viden og lave skriftlig dokumentation. Erfaringsmæssigt er skrivning også et vigtigt redskab ved refleksion og udvikling af forståelsesformer (Nielsen og Kjeldsen 2009). Ved tilrettelæggelse af et e-læringsforløb må underviserne derfor overveje, hvilke aktivitetsformer der er bedst egnet til at styrke den skriftlige interaktion.

En fordel ved skriftlig interaktion er, at skriftsproget er mindre flygtigt end talesproget. I modsætning til mundtlig respons, kan deltagerne genlæse skriftlig respons og kommentarer lige så ofte, de har behov for det. De kan også drage nytte af skriftlig interaktion i praktikperioder, hvor fælles samlinger ikke er mulige. I forbindelse med praktikophold kan de for eksempel reflektere over forhold som "praksischok" og behov for kompetenceudvikling. Egne refleksioner og feedback fra vejledere kan både inspirere til handling og ændret handling (Nielsen og Kjeldsen 2009). Evalueringer peger på, at deltagerne kan have stort udbytte af at forberede og bearbejde erfaringer fra praktikophold sammen med deres vejledere og andre deltagere via et digitalt dialogforum (Fregerslev og Jørgensen 2000).

\section{Portfolioevaluering}

Ved design af e-læring må underviserne tage stilling til, hvordan deltagerne skal formidle deres analyser, produkter og refleksioner. Til at begynde med må underviserne og deltagerne blive enige om, hvad deltagerne skal gemme, hvor det skal gemmes og hvordan det skal anvendes. Efterhånden falder valget ofte på en "cloud"-løsning, dvs. en digital portfolio som skabes af deltagerne, og som de har adgang til 24/7. 
En portfolio anvendes inden for mange fagområder, når deltagerne kan løse en åben opgave, belyse et problem eller fremstille et produkt på mere end én måde (Lindström 1997). Heri indgår ofte beskrivelse af idéer og planer, skitser, forstudier, baggrundsinformation om emner eller genrer, refleksioner og selvevaluering af det afsluttede arbejde (Lindström 2007). Deltagerne kan nærmere bestemt samle beskrivelser af planlagte arbejder, problemstillinger, udkast til igangværende arbejder, færdige produkter og deres refleksioner over egen læring i deres portfolio (fig. 3). Hvis refleksionerne mangler, er det ikke en portfolio, men blot en digital mappe.

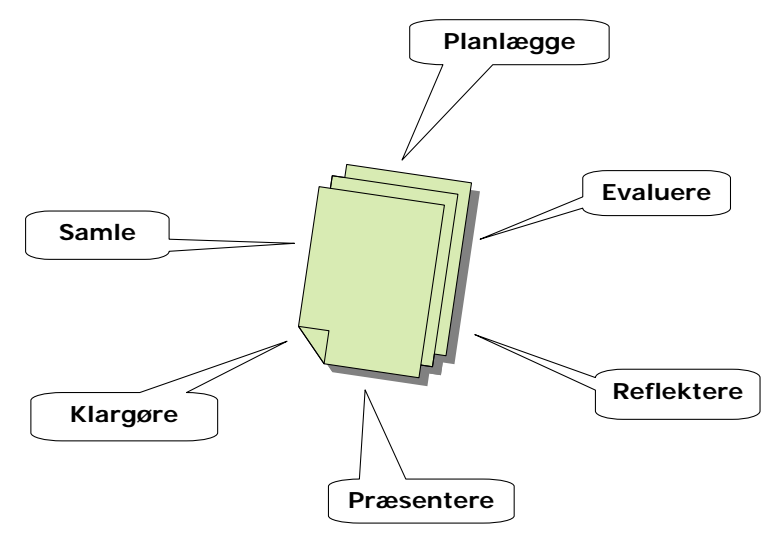

Figur 3.

Deltagernes refleksioner har ikke karakter af dagbog. Indholdet er personligt, men det er ikke privat, idet underviserne kan læse med og løbende kommentere og give feedback. Jo mere deltagerne reflekterer over deres besvarelser af åbne opgaver, analyser og egenproduktioner, jo bedre kan underviserne få kendskab til deres forventninger til arbejdet og vurdere værdien heraf for deres læring.

Evalueringer peger på, at anvendelsen af digitale portfolioer medvirker til at skabe sammenhæng og synliggøre fremdriften i deltagernes kompetenceudvikling under deres praktikophold (EVA 2003). Den kvalificerer også undervisernes feedback på skriftlige arbejder og styrker deltagernes evaluering af egen læring. Selvevaluering - og i det hele taget reflekterende tilbageblik på hidtidige arbejder - medvirker til at bringe deltagernes oplevelser ind i sproget og befordrer en erfaringsdannelse, som kommer dem til nytte ved kommende læringsaktiviteter.

Som nævnt er feedback en af de faktorer, der har størst betydning for kvaliteten af undervisning og e-læring. En fejlslutning i den forbindelse er, at det primært er deltagerne, der har gavn af at få feedback på deres igangvæ- 
rende og færdige arbejder (Hattie 2009). Det er i lige så høj grad underviserne, der har gavn heraf. Ved at følge og kommentere fremdriften i deltagernes læring, kan underviseren blive opmærksom på begreber og emner, som trænger til at blive behandlet yderligere. De kan også blive opmærksomme på eventuelle vanskeligheder med at forstå undervisningens hvorfor og hvordan, herunder om deltagerne kan se meningen med deres selvstændige aktiviteter, kender forventningerne til disse aktiviteter og er i stand til at organisere og tilrettelægge disse aktiviteter.

Som nævnt er kollaborativ læring i mange tilfælde en mere effektiv form for læring end individuel læring og konkurrencepræget performance. En af grundene til det er den gensidige undervisning, som finder sted, når deltagerne kommenter hinandens forslag og udkast, og som generelt har stor effekt på læringsudbyttet (Petty 2006). Den gensidige undervisning kan f.eks. finde sted i forbindelse med samarbejder om at løse åbne opgaver, belyse problemstillinger, analysere cases eller frembringe produkter.

\section{Konklusion}

I artiklen præsenteres resultater af fagdidaktisk forskning som belæg for, at e-læring kan føre til bedre læringsresultater end traditionel undervisning, der er tilrettelagt som en perlerække af fælles samlinger. Sammenlignet med skemalagt holdundervisning kan underviserne lettere tilrettelægge en vekselvirkning af fælles samlinger og perioder med selvstændige aktivitetsformer, hvor deltagerne gør førstehåndserfaringer med faglige arbejdsmetoder samt udvikler deres forståelse af faglige emner og kendskab til faglige begreber.

Ved indførelse af differentieret e-læring øges undervisernes metodefrihed, og der styres på mål frem for på tid. Mål og indhold bestemmer rammerne for deltagernes aktiviteter frem for omvendt. Kombinationen af et tydeligt design af e-læringsforløb og et tæt fagligt samspil med deltagerne kan øge læringsudbyttet. Ved hensigtsmæssig anvendelse af netbaseret information og dialog kan underviserne opnå, at deltagerne kender forventningerne og kan se meningen med dét, de foretager sig under et læringsforløb. Desuden styrkes undervisernes mulighed for at vejlede, når behovet opstår, og evaluere og give feedback på indhold i deltagernes digitale portfolioer.

Set fra undervisernes side er det ikke den digitale teknologi som sådan, der gør en forskel, men den måde, hvorpå de anvender teknologien til at få kendskab til deltagernes refleksioner, opgavebesvarelser, analyser og produkter samt være empatisk og give handlingsorienteret feedback. 


\section{Referencer}

Andresen, B. B. (1999). Fleksibel læring for voksne - fra fjernundervisning til netbaseret teamlæring. Århus: Systime.

Andresen, B. B. (2001). Kvalitet i e-læring. København: Chr. Ejlers Forlag.

Andresen, B. B. (2007). Literacy, assistive technology and e-inclusion. Journal of Assistive Technologies, Vol. 1/1.

Bjerre, S., Christensen, G. og Steinmüller, L. (2009). Vejledning om mobil elæring. Århus: @ventures eVidenCenter, Det Nationale Videncenter for e-læring. Lokaliseret den 1. september 2009 på www: www.itst.dk/elaering-og-it-faerdigheder/e-lering/rapporter-ograpporter/Temahefte mobil e-lering.pdf.

Black, P. \& Wiliam, D. (1998): Assessment and Classroom Learning. Assessment in Education: Principles, Policy \& Practice. Vol. 5, Issue 1.

EVA (2003). Læreruddannelsen. København: Danmarks Evalueringsinstitut. Lokaliseret den 1. februar 2009 på www: www.eva.dk/projekter/2002/evaluering-aflaereruddannelsen/projektprodukter/laereruddannelsen/download.

Damberg, E. (2009). (Red.). Fag og didaktik - med fagsamspil som udfordring. Konferencerapport. Gymnasiepædagogik. Nr. 72. Lokaliseret den 1. februar 2010 på www: www.sdu.dk/ /media/Files/Om SDU/Institutter/Ifpr/Gymnasiepaedg ogik/72.ashx.

Fregerslev, P. \& Jørgensen, M. (2000). Ny lærer. Om de første to år med sytten nyuddannede lærere. Århus: Århus Dag- og Aftenseminarium.

Gardner, H. (2000). Disciplin og dannelse - betydningen af det sande, det smukke og det gode. København: Gyldendal Uddannelse.

Hattie, J. A. C. (2009). Visible learning. A synthesis of over 800 meta-analyses relating to achievement. Abingdon: Routledge.

Kress, G. (2003). Literacy in the new media age. London: Routledge.

Larsen, C. Aa. (1997). Artikler. I: Jensen, E. (Red.). Didaktiske emner. København: Danmarks Pædagogiske Bibliotek.

Larsen, V. (2006). På sporet af nye læringsrum. Baggrundsartikler til konferencen "Anderledes læringsmiljøer". Lokaliseret den 1. september 2009 på www: www.medieintegreret.socialfonden.net/files/upload/Den\%20gode $\% 20$ bland\%20Konf.pdf. 
Lindström, L. (1997). Portföljen som examinationsform. Häften för didaktiske studier nr. 64. Lärerhögskolan i Stockholm.

Lindström, L. (2007). Kan kreativitet läras ut? En bildpedagogisk översikt. EDUCARE, nr. 1, 7-32.

Nielsen, K. og Kjeldsen, L. P. B. (2009). Når e-portfolio bygger bro mellem teori og praksis. Undervisning og e-portfolio i sygeplejerskeuddannelsen i VIA. Årsskrift for Udviklingsdivisionen 2009. Århus: VIA University College.

Nordenbo, S. E. et al. (2008). Lærerkompetanser og elevers læring $i$ barnehage og skole - et systematisk review utført for Kunnskapsdepartementet, Oslo. København: Danmarks Pædagogiske Universitetsforlag.

Petty, G. (2006). Evidence-based teaching. Cheltenham: Nelson Thornes.

Steinmüller, L. M. (2001). Pædagogik og e-læring. J.A.K. bladet. Nr. 3. Lokaliseret den 1. februar 2010 på www: www.jak.dk/forening/z301 E-laering.htm.

OECD (2005). The definition and selection of key competencies. Executive summary. Lokaliseret den 1. februar 2009 på www: http://www.oecd.org/dataoecd/47/61/35070367.pdf

U.S. Department of Education (2009). Evaluation of Evidence-Based Practices in Online Learning: A Meta-Analysis and Review of Online Learning Studies, Washington, D.C.: Office of Planning, Evaluation, and Policy Development. Lokaliseret den 1. februar 2010 på www: www2.ed.gov/rschstat/eval/tech/evidence-basedpractices/finalreport.pdf.

Wikipedia (2010). WebQuest. Lokaliseret den 1. februar 2010 på www: http://da.wikipedia.org/wiki/Webquest. 